\title{
Identification of surface-exposed Yersinia pestis proteins by radio-iodination and biotinylation
}

\author{
F. G. C. ABATH, A. M. P. ALMEIDA and L. C. S. FERREIRA*
}

Laboratório de Immunopatologia Keizo Asami, Universidade Federal de Pernambuco and Centro de Pesquisas Aggeu Magalhães, Cidade Universitária, Recife, PE, 50739, Brazil

\begin{abstract}
Summary. When whole cells (stationary phase) of Yersinia pestis strain EV76 were radiolabelled with Iodogen and ${ }^{131}$ I, 16 major and 10 minor surface-exposed outer membrane proteins (OMPs) were identified. Labelling with $\mathrm{N}$-hydroxysuccinimidyl 6-biotinylaminohexanoate (biotin X-NHS) resulted in a complex protein profile detectable after blotting and developing with peroxidase-conjugated avidin. $Y$. pestis cell fractionation revealed that biotin X-NHS labelled not only OMPs but also proteins of inner cell compartments. Therefore, radiolabelling was the more reliable technique for identifying the OMPs of $Y$. pestis.
\end{abstract}

\section{Introduction}

The outer membrane of gram-negative bacteria is usually the outermost cell envelope layer. Some surface-exposed outer membrane proteins (OMPs) play a role in invasion, adherence and ability to evade pestis, the aetiological agent of plague, ${ }^{2}$ is a gramnegative organism whose plasmid-coded OMPs are associated with survival and growth in vivo. ${ }^{3,4}$

The surface proteins of several bacterial species have been identified by iodination with membrane-impermeable enzymes ${ }^{5-8}$ or the water insoluble reagent $1,3,-$ 4,5,6-tetrachloro-3,6-diphenylglycouril (Iodogen). ${ }^{9-11}$ Labelling with Iodogen has proved reliable for viruses, bacteria and eukaryotic cells, ${ }^{12-14}$ but the handling of radioactive material and the short half-life of ${ }^{125} \mathrm{I}$ or ${ }^{131} \mathrm{I}$ are serious drawbacks.

The avidin-biotin system is a useful alternative for cell-labelling and affinity isolation techniques. ${ }^{15-17}$ Biotin derivatives conjugated with $\mathrm{N}$-hydroxysuccinimide were synthesised for the specific labelling of proteins and peptides under mild conditions. ${ }^{18} \mathrm{Re}-$ cently, a new biotin derivative, N-hydroxysuccinimidyl 6-biotinylamidohexanoate (biotin X-NHS), was used for the specific labelling of cell-surface proteins of embryonic neural chick cells. ${ }^{19}$ It is an ideal reagent for the electrophoretic analysis of cell surface components because it binds to molecules under mild conditions and does not penetrate cell membranes or interfere with one- or two-dimensional gel electrophoresis. However, the use of this technique for labelling the cell humoral and cellular defence mechanisms. ${ }^{1}$ Yersinia

surface proteins of gram-negative bacteria has not been evaluated.

This study compared the effectiveness of Iodogencatalysed iodination and biotinylation with biotin XNHS for the specific labelling of $Y$. pestis OMPs.

\section{Materials and methods}

\section{Bacteria and growth conditions}

Y. pestis strain EV76, kindly donated by Dr R. R. Brubaker, was used. Cells were grown in YT medium (tryptone $1 \%$, yeast extract $0.5 \%, \mathrm{NaCl} 0.5 \%$ ) at $28^{\circ} \mathrm{C}$ up to the stationary phase.

\section{Radio-iodination of intact cells}

The $Y$.pestis cells were radio-iodinated as previously described. ${ }^{9}$ Stationary phase cells were washed twice in phosphate-buffered saline (PBS) and suspended to a final concentration of $10^{9}$ cells $/ \mathrm{ml}$. The cell suspension $(0.2 \mathrm{ml})$ was allowed to react with $300 \mu \mathrm{Ci}$ of carrierfree ${ }^{131} \mathrm{I}$ (IPEN, São Paulo, Brazil) $(10 \mathrm{mCi} / \mathrm{ml})$ in reaction vials containing $45 \mu \mathrm{g}$ of Iodogen (Pierce Chemical Co., Rockford, USA) for 90,45 or $30 \mathrm{~s}$ at room temperature. Radio-iodination was interrupted by transferring the samples to another tube containing $3 \mathrm{ml}$ of $10 \mathrm{~mm} \mathrm{NaI}$, followed by three washes with the same solution and one wash with $0.5 \mathrm{M}$ Tris- $\mathrm{HCl}$ (pH 6.8). Labelled cells were solubilised in electrophoresis sample buffer and subjected to electrophoresis and autoradiography.

\section{Biotinylation of intact cells}

* Present address: Instituto de Biofísica Carlos Chagas Filho, Universidade Federal do Rio de Janeiro, 21949 Rio de Janeiro, RJ, Brazil.
The $Y$. pestis cells were biotinylated by a previously published procedure ${ }^{19}$ Cells corresponding to $0.2 \mathrm{ml}$ 


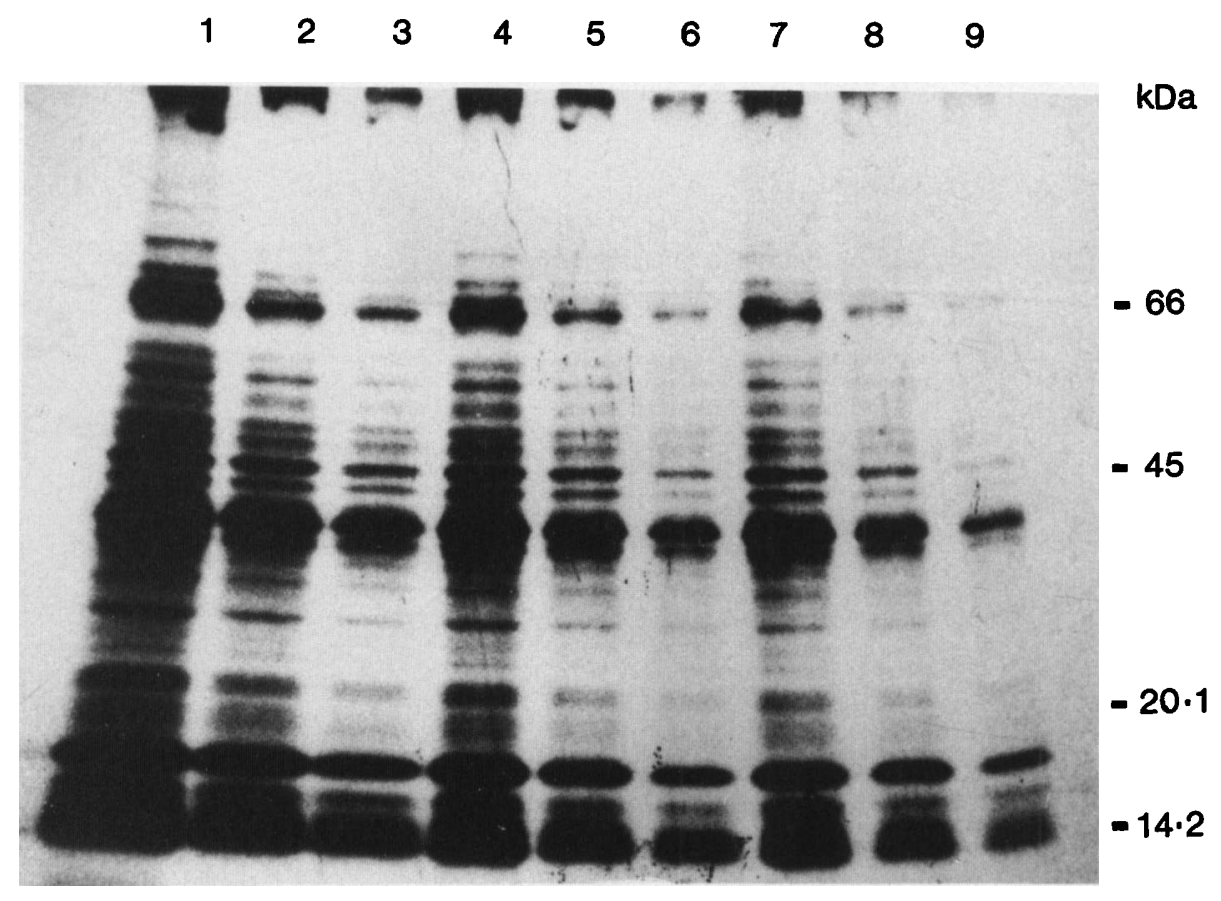

Fig. 1. Autoradiogram of Iodogen-catalysed iodination of stationary phase $Y$. pestis cells grown at $28^{\circ} \mathrm{C}$. Cells were labelled with Iodogen and ${ }^{131}$ I for 90 (lanes $\left.1,4,7\right), 45(2,5,8)$, and $30(3,6,9) \mathrm{s}$. Different amounts of protein were applied in each run: $64 \mu \mathrm{g}(1,2,3), 32 \mu \mathrm{g}(4,5,6)$ and $16 \mu \mathrm{g}(7,8,9)$. After separation on SDS-PAGE, gels were exposed to X-ray film for $24 \mathrm{~h}$ at $-80^{\circ} \mathrm{C}$. The amount of radioactivity in each sample ranged from 8000 to $90000 \mathrm{cpm}$.

of a stationary phase culture were washed twice with labelling buffer $(\mathrm{NaCl} 8 \mathrm{~g}, \mathrm{KCl} 0.4 \mathrm{~g}$, glucose $1 \mathrm{~g}$, $\mathrm{MgSO}_{4} .7 \mathrm{H}_{2} \mathrm{O} 0.2 \mathrm{~g}, \mathrm{CaCl}_{2} .2 \mathrm{H}_{2} \mathrm{O} 0.2 \mathrm{~g}$, and $\mathrm{NaHCO}_{3}$ $0.5 \mathrm{~g} / \mathrm{L}, \mathrm{pH} \mathrm{7.4)}$ and then transferred to an Eppendorf tube containing different amounts of biotin X-NHS (Calbiochem Boehring Diagnostics, La Jolla, CA, USA) solubilised in dimethyl formamide (Fluka, Buchs, Switzerland) for $10 \mathrm{~min}$ at room temperature. After labelling, cells were washed twice with M9 medium containing casamino acids $\left(\mathrm{Na}_{2} \mathrm{HPO}_{4} 0.6 \%\right.$, $\mathrm{KH}_{2} \mathrm{PO}_{4} 0.3 \%, \quad \mathrm{NaCl} 0.05 \%, \mathrm{NH}_{4} \mathrm{Cl} 0.01 \%$, casamino acids $0.02 \%$; Difco). The cells were solubilised in sample buffer and subjected to SDS-PAGE and blot transfer.

\section{Fractionation of $Y$. pestis cells}

$Y$. pestis cells were fractionated by the procedure described previously for the solubilisation of cytoplasmic membrane proteins with Sarkosyl ${ }^{20}$ Cells were washed in PBS, suspended in $10 \mathrm{mM}$ Tris- $\mathrm{HCl}$ (pH 7.8), $5 \mathrm{~mm}$ EDTA and $1 \mathrm{~mm}$ 2-mercaptoethanol and disrupted in a model $200 \mathrm{M}$ refrigerated ultrasonic disintegrator (Kubota, Tokyo, Japan) at full power for $10 \mathrm{~min}$. Cell debris was removed by low speed centrifugation and the envelope fraction was pelleted at $100000 \mathrm{~g}$ for $1 \mathrm{~h}$. The supernate was considered to be the soluble fraction (periplasmic and cytoplasmic material). The membrane pellet was suspended in a solution containing Sarkosyl $0.5 \%$ and $1 \mathrm{~mm} \mathrm{2-}$ mercaptoethanol, incubated at $4^{\circ} \mathrm{C}$ for $18 \mathrm{~h}$ and then centrifuged at $100000 \mathrm{~g}$ for $1 \mathrm{~h}$ at $4^{\circ} \mathrm{C}$ to obtain the outer-membrane fraction. The Sarkosyl-soluble supernate was considered to be the cytoplasmic membrane-enriched fraction. Fractionation of biotinylated cells necessitated extensive washing (six cycles) of the labelled cells with M9 medium containing casamino acids and incorporation of carrier cells $(4.8 \mathrm{ml}$ of nonlabelled stationary phase cells to $0 \cdot 2 \mathrm{ml}$ of biotinylated cells) before the sonic disruption and processing.

\section{SDS-PAGE and blot transfer}

SDS-PAGE of $Y$. pestis extracts was performed according to the method of Laemmli. ${ }^{21}$ Improved protein separation was achieved in acrylamide $15-10 \%$ gradient gels. Samples solubilised in Laemmli sample buffer ${ }^{21}$ were incubated at $95^{\circ} \mathrm{C}$ for $10 \mathrm{~min}$ and subjected to electrophoresis at a constant current of $20 \mathrm{~mA}$. Proteins separated on acrylamide gels were transferred to nitrocellulose sheets as described previously ${ }^{22}$ After blotting, the nitrocellulose sheets were incubated overnight with albumin $1 \%$ in PBS (pH 7.0). The blots were treated with horseradish peroxidase conjugated avidin (Calbiochem Boehring Diagnostics, 1 in 4000 dilution in PBS) for $10 \mathrm{~min}$ and washed twice with PBS. The blots were developed with 4-chloro-1-naphthol (Sigma) $0.5 \mathrm{mg} / \mathrm{ml}$ and $\mathrm{H}_{2} \mathrm{O}_{2} 0.015 \%$.

\section{Radioactivity measurements}

Autoradiography was carried out with frozen gels $\left(-80^{\circ} \mathrm{C}\right.$ for $\left.24 \mathrm{~h}\right)$ and Kodak X-Omat XAR-2 film (Eastman Kodak Co., Rochester, NY, USA). Radioiodinated samples in aqueous solution were counted 


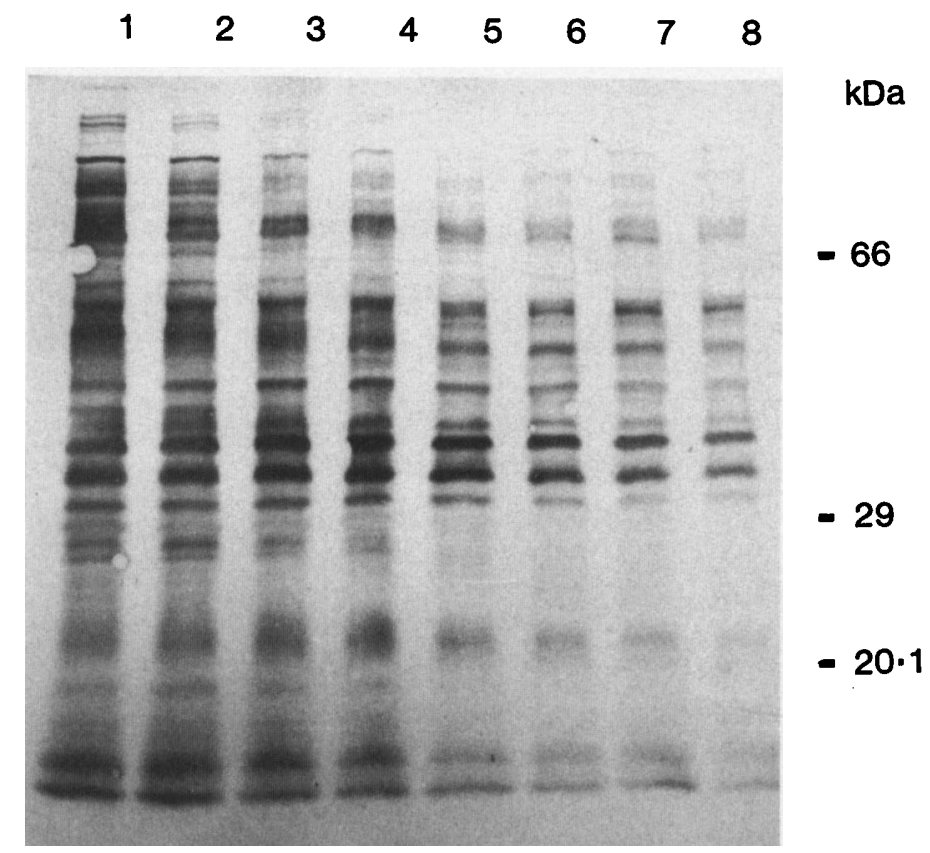

Fig. 2. $Y$. pestis protein labelled with different amounts of biotin X-NHS. Each sample contained intact $Y$. pestis cells, grown at $28^{\circ} \mathrm{C}$, corresponding to $0.2 \mathrm{ml}$ of stationary phase cells $(4.5 \mathrm{mg}$ wet weight). The amount of biotin X-NHS used in each reaction was $1 \mathrm{mg}$ (lane 1 ), $500 \mu \mathrm{g}(2), 250 \mu \mathrm{g}(3), 125 \mu \mathrm{g}(4), 62.5 \mu \mathrm{g} \mathrm{(5),31.25} \mu \mathrm{g}(6), 15-12 \mu \mathrm{g} \mathrm{(7),} 7.5 \mu \mathrm{g}(8)$. Each sample contain $25 \mu \mathrm{g}$ of protein. The labelling period was $10 \mathrm{~min}$.

in a model G-20 gamma counter (Mini Instrument, Essex).

\section{Other methods}

Protein concentration was determined according to the method of Lowry et al. ${ }^{23}$

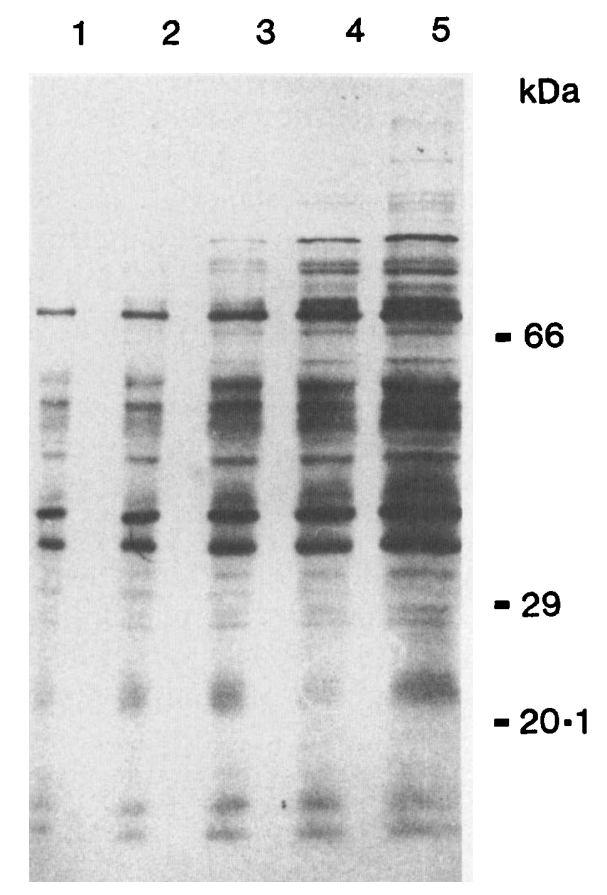

Fig. 3. Labelling of $Y$. pestis cells with biotin X-NHS for different incubation times. Stationary phase cells grown at $28^{\circ} \mathrm{C}$ were incubated with biotin X-NHS (1 mg) for $30 \mathrm{~s}$ (lane 1), $1 \mathrm{~min}(2)$, $3 \mathrm{~min}(3), 5 \mathrm{~min}(4)$ and $10 \mathrm{~min}(5)$. Samples containing $25 \mu \mathrm{g}$ of protein were applied on the gel.

\section{Results}

\section{Radio-iodination of intact $Y$. pestis cells}

Sixteen protein bands were regularly detected in $Y$. pestis whole cells labelled with Iodogen and ${ }^{131} \mathrm{I}$. A further set of 10 minor OMPs could be seen also, but their optimal resolution depended on sample preparation, electrophoresis and exposure time. The most prominent OMPs detected in autoradiograms had mol. wts of $65,39,32-35$ and $12 \mathrm{kDa}$. A heavily labelled broad band migrating to a position of $32-35 \mathrm{kDa}$ was formed by a triplet not clearly distinguished on autoradiograms but easily resolved on silver-stained SDS-PAGE gels. These proteins were represented by the protein $\mathrm{E}$ and probably two other porin-like proteins also exposed on the cell surface (data not shown). An estimation of the optimal labelling period and ideal protein load was performed to obtain a better resolution on autoradiograms after exposure for $24 \mathrm{~h}$ (fig. 1). Best results were obtained with a labelling period of $45 \mathrm{~s}$ and $32 \mu \mathrm{g}$ of total protein/well.

\section{Biotinylation of intact Y. pestis cells}

The labelling of $Y$.pestis whole cells with biotin XNHS resulted in a complex protein profile composed of at least 30 major bands of different staining intensities on blots. The most prominent bands revealed by this technique were clearly distinct from the $Y$. pestis OMPs detected in silver-stained gels or after Iodogen-catalysed iodination of surface-exposed proteins. To establish the best labelling conditions for biotin X-NHS, different ratios of biotin to bacterial 


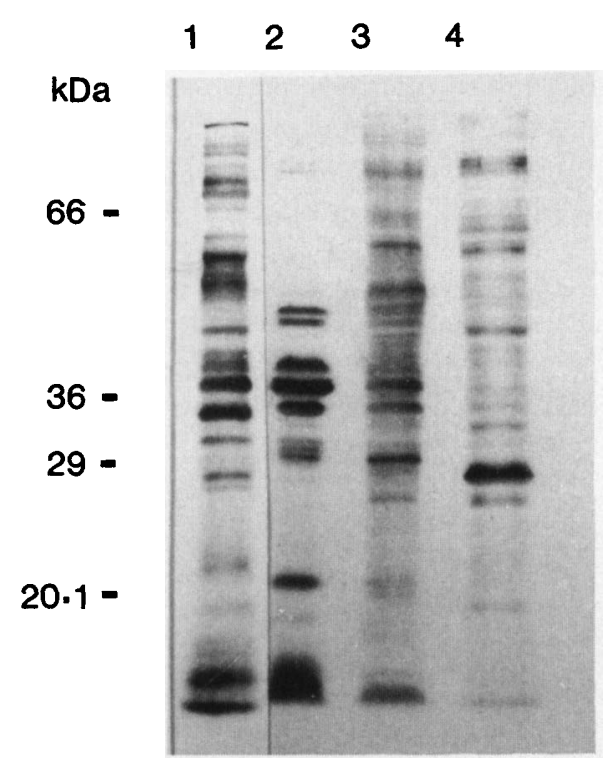

Fig. 4. Fractionation of $Y$. pestis cells labelled with biotin X-NHS. Proteins from total cell extracts (lane 1), outer membranes (2), inner membranes (3) and soluble fractions (4) were separated on SDSPAGE and transferred to nitrocellulose sheets. Each sample contained $25 \mu \mathrm{g}$ of total protein.

cells were used. Decreasing amounts of biotin X-NHS were used to label a fixed amount of cells, corresponding to $0.2 \mathrm{ml}$ of stationary phase $Y$.pestis culture ( $4.5 \mathrm{mg}$ wet weight; fig. 2). With a labelling period of $10 \mathrm{~min}, 1 \mathrm{mg}$ of biotin/reaction gave the best results. The influence of the labelling period on the profile of biotinylated surface proteins was also evaluated. Biotinylation of the most prominent proteins was observed after labelling periods as short as $30 \mathrm{~s} \mathrm{(fig.} \mathrm{3).}$ However, several additional bands were detected after prolonged labelling periods.

\section{Fractionation of biotinylated $Y$. pestis}

The increasing number of peptides identified in cells labelled for prolonged periods with biotin may indicate a permeation of biotin X-NHS to inner compartments of the $Y$. pestis cell and consequent labelling of intracellular proteins. Fractionation of biotinylated $Y$. pestis into soluble components (periplasm and cytoplasm), cytoplasmic membrane and outer membrane indicated that biotinylation of whole cells resulted in the labelling of soluble and cytoplasmic membrane proteins (fig. 4).

\section{Discussion}

Surface proteins of Vibrio cholerae,${ }^{10}$ Neisseria gonorrhoeae, ${ }^{11,24}$ Escherichia coli ${ }^{9}$ Treponema pallidum ${ }^{25}$ and Aeromonas salmonicida ${ }^{6}$ have been identified by the Iodogen-catalysed iodination technique. The results of this study strongly suggest that the proteins detected by the Iodogen procedure are indeed surfacelocated. The protein profile obtained in autoradiograms after radio-iodination of intact $Y$. pestis cells was remarkably similar to the band pattern of isolated outer membranes after SDS-PAGE. ${ }^{26}$ Sixteen major proteins and 10 other minor bands were detected in stationary phase $Y$. pestis cells grown at $28^{\circ} \mathrm{C}$. This number represents almost all the OMPs of this organism detected in silver-stained SDS-PAGE ${ }^{26}$ and approximately half of the OMPs detected in twodimensional gels. ${ }^{27}$ Increased amounts of cells and longer reaction periods did not change the number of proteins specifically labelled by this procedure (fig. 1). Moreover, only traces of radioactive contamination, represented by OMPs, could be found in cytoplasmic membrane after fractionation of radiolabelled cells ${ }^{9}$ (and unpublished observations). Additional evidence of the surface-exposed nature of proteins identified by Iodogen-catalysed iodination would be their recognition by antibodies produced against intact $Y$. pestis cells. The profile of proteins recognised by specific anti- $Y$. pestis sera on immunoblots shares several features with the set of proteins labelled by Iodogen. ${ }^{28,29}$ At least eight major Iodogen-labelled OMPs were recognised by the sera of guinea-pigs immunised with $Y$. pestis or by sera from convalescent plague patients. ${ }^{30}$ These observations further emphasise that the Iodogen-catalysed iodination of $Y$. pestis cells is restricted to surface-located OMPs.

Apart from lectins, protein A and antibodies, the avidin-biotin complex represents an excellent binding system for characterising chemical and biological materials. Properties of avidin and biotin relevant to their use as technical tools include high affinity $(\mathrm{KD}<$ $10^{-15} \mathrm{M}$ ) and multivalent binding for free and conjugated biotin, great stability, relatively small size, homogeneity, ready availability, the polar nature of biotin, and easy attachment of biotin to other macromolecules. ${ }^{15,17,31}$

Attempts to identify surface-exposed proteins with the avidin-biotin method have been restricted mainly to eukaryotic cells, e.g., leucocytes, ${ }^{16}$ trypanosomes $^{32,33}$ and nematodes. ${ }^{34}$ In particular, biotin X-NHS was used for selective labelling, isolation and electrophoretic analysis of surface proteins of embryonic chick retina cells. ${ }^{19}$ However, the labelling of $Y$. pestis cells with biotin X-NHS showed that this compound can permeate the cell envelope.

The failure to label specifically the surface proteins of $Y$. pestis with biotin X-NHS may have been due to its low mol. wt (454.3) which is well below the exclusion limit of the outer-membrane hydrophilic pores. Moreover, gram-negative bacteria are endowed with a specific biotin transport system, including outer-membrane receptors, responsible for the intracellular accumulation of this vitamin. ${ }^{35}$ Attempts to block the penetration of biotin X-NHS into the cells by changing the labelling conditions, e.g., by altering the composition of the labelling buffer, adding osmoprotectants such as proline, or incubating at different temperatures, did not change the results (data not shown).

Some $Y$. pestis OMPs could be detected readily by the biotin X-NHS reagent but others could not be 
labelled even in reactions with isolated outer membranes (fig. 4, and unpublished results). One possible explanation is the varied amino-acid composition of the proteins and the different specificities of Iodogen and biotin X-NHS, which mainly catalyse the binding of surface-exposed tyrosine and lysine residues respectively.

The present study has shown that Iodogen-catalysed iodination is more specific than biotin X-NHS for

\section{References}

1. Finlay BB, Falkow S. Common themes in microbial pathogenicity. Microbiol Reviews 1989; 53: 210-230.

2. Poland JD, Barnes AM. Plague. In: Steele JF (ed) CRC Handbook Series in Zoonoses, vol. 1, section A, Bacterial, rickettsial and mycotic disease. Boca Raton, CRC Press. 1979: 516-556.

3. Bölin I, Portnoy DA, Wolf-Watz H. Expression of the temperature-inducible outer membrane proteins of Yersiniae. Infect Immun 1985; 48: 234-240.

4. Portnoy DA, Wolf-Watz H, Bölin I, Beeder AB, Falkow S. Characterization of common virulence plasmids in Yersinia species and their role in the expression of outer membrane proteins. Infect Immun 1984; 43: 108-114.

5. Heckels JE. The surface properties of Neisseria gonorrhoeae: topographical distribution of the outer membrane protein antigens. J Gen Microbiol 1978; 108: 213-219.

6. Kay WW, Buckley JT, Ishiguro EE, Phipps BM, Monette JPL, Trust TJ. Purification and disposition of a surface protein associated with virulence of Aeromonas salmonicida. $J$ Bacteriol 1981; 147: 1077-1084.

7. Lambert PA, Booth BR. Exposure of outer membrane proteins on the surface of Pseudomonas aeruginosa PA01 revealed by labeling with $\left({ }^{125} \mathrm{I}\right)$-lactoperoxidase. FEMS Microbiol Lett 1982; 14: 43-45.

8. Munford RS, Gotschlich EC. Iodination of Escherichia coli with chloramine $T$ selective labeling of the outer membrane lipoprotein. J Bacteriol 1977; 130: 775-780.

9. Ferreira LCS, Almeida DF. Iodogen catalysed iodination for identification of surface-exposed outer membrane proteins of Escherichia coli K12. Braz J Genetics 1987; 10: 625-634.

10. Richardson $K$, Parker $C D$. Identification and characterization of Vibrio cholerae surface proteins by radioiodination. Infect Immun 1985; 48: 87-93.

11. Swanson J. Surface-exposed protein antigens of the gonococcal outer membrane. Infect Immun 1981; 34: 804-816.

12. Concino MF, Goodgal SH. Haemophilus influenzae polypeptides involved in deoxyribonucleic acid uptake detected by cellular surface protein iodination. $J$ Bacteriol 1981 ; 148: 220-231.

13. Fraker PJ, Speck JC. Protein and cell membrane iodinations with a sparingly soluble chloramide 1,3,4,6-tetrachloro-3a, 6-a diphenylglycoluril. Biochem Biophys Res Commun 1978; 80: 849-857.

14. Markwell MAK, Fox CF. Surface-specific iodination of membrane proteins of viruses and eukaryotic cells using 1,3,4,6-tetrachloro-3- $\alpha, 6-\alpha$, diphenylglycoluril. Biochemistry $1978 ; 17: 4807-4817$.

15. Bayer EA, Wilchek $M$. The avidin-biotin complex as a tool in molecular biology. Trends Biochem Sci 1978; 3: 257-259.

16. Hurley WL, Finkelstein E, Holst BD. Identification of surface proteins on bovine leukocytes by a biotin-avidin protein blotting technique. J Immunol Methods 1985; 85: 195-202.

17. Wilchek M, Bayer EA. The avidin-biotin complex in bioanalytical applications. Anal Biochem 1988; 171 : 1-32.

18. Hofmann K, Titus G, Montibeller JA, Finn FM. Avidin binding of carboxyl-substituted biotin and analogues. Biochemistry 1982; 21: 978-984. labelling $Y$. pestis surface-exposed proteins. However, because of its simplicity, safety and successful application to eukaryotic cells, biotin-mediated labelling of surface-exposed proteins of gram-negative bacteria should be studied further with larger biotin derivatives or improved labelling conditions.

We acknowledge the skilful technical assistance of S. H. Almeida and Y. Nakasawa. This research was supported by the Japanese International Cooperation Agency and CNPq.

19. Van Boxberg Y, Wütz R, Schwarz U. Use of the biotin-avidin system for labelling, isolation and characterization of neural cell-surface proteins. Eur J Biochem 1990; 190: 249-256.

20. Bölin I, Norlander L, Wolf-Watz H. Temperature-inducible outer membrane protein of Yersinia pseudotuberculosis and Yersinia enterocolitica is associated with the virulence plasmid. Infect Immun 1982; 37: 506-512.

21. Laemmli UK. Cleavage of structural proteins during the assembly of the head of bacteriophage T4. Nature 1970 . 227: 680-685.

22. Towbin H, Staehelin T, Gordon J. Electrophoretic transfer of proteins from polyacrylamide gels to nitrocellulose sheets. Procedure and some applications. Proc Natl Acad Sci USA $1979 ; 76$ : 4350-4354.

23. Lowry OH, Rosebrough NJ, Farr AL, Randall RJ. Protein measurement with the folin phenol reagent. $J$ Biol Chem 1951; 193: 265-275.

24. Sullivan KH, Williams RP. Use of Iodo-gen and iodine-125 to label the outer membrane proteins of whole-cells of Neisseria gonorrhoeae. Anal Biochem 1982; 120: 254-258.

25. Norris SJ, Sell S. Antigenic complexity of Treponema pallidum antigenicity and surface localization of major polypeptides. J Immunol 1984; 133: 2686-2692.

26. Abath FGC, Almeida AMP, Ferreira LCS. Electrophoretic characterisation of the outer membrane proteins of $\mathrm{Yer}$ sinia pestis isolated in North-east Brazil. Epidemiol Infect 1989; 103: 595-602.

27. Darveau RP, Charnetzky WT, Hurlbert RE, Hancock REW. Effects of growth temperature, 47-megadalton plasmid, and calcium deficiency on the outer membrane protein porin and lipopolysaccharide composition of Yersinia pestis EV76. Infect Immun 1983; 42: 1092-1101.

28. Massa G, Karu AE, Kingsbury DT. Immune response to plasmid- and chromosome-encoded Yersinia antigens. Infect Immun 1985; 48: 676-685.

29. Skurnik M. Expression of antigens encoded by the virulence plasmid of Yersinia enterocolitica under different growth conditions. Infect Immun 1985; 47: 183-190.

30. Abath FGS, Almeida AMP, Ferreira LCS. Surface-exposed antigenic determinants in outer membranes of wild Yersinia pestis isolates. Zentralbl Bakteriol 1992; 276: 73-85.

31. Costello SM, Felix RT, Giese RW. Enhancement of immune cellular agglutination by use of an avidin-biotin system. Clin Chem 1979; 25 : 1572-1580.

32. Evans TG, Krug EC, Wilson ME, Vasconcelos AW, de Alencar JE, Pearson RD. Evaluation of antibody responses in American visceral leishmaniasis by ELISA and immunoblot. Mem Inst Oswaldo Cruz 1989; 84: 157-166.

33. Gardiner PR, Pearson TW, Clarke MW, Mutharia LM Identification and isolation of a variant surface glycoprotein from Trypanosoma vivax. Science 1987; 235: 774-777.

34. Alvarez RM, Henry RW, Weil GJ. Use of Iodogen and sulfosuccinimidobiotin to identify and isolate cuticular proteins of the filarial parasite Brugia malayi. Mol Biochem Parasitol 1989; 33: 183-189.

35. Eisenberg $M$. Biosynthesis of biotin and lipoic acid. In Neidhardt FC (ed) Escherichia coli and Salmonella typhimurium. Cellular and molecular biology. Washington, American Society for Microbiology. 1987: 544-550. 